\title{
Seasonal Variation of Cations and Anions in a Concrete Fish Tank
}

\author{
Bawa, D. Y. and Obaroh, I. O. \\ Department of Forestry and Fisheries Kebbi State University of Science and Technology, Aliero, Nigeria \\ Department of Biological Sciences Kebbi State University of Science and Technology, Aliero, Nigeria
}

\begin{abstract}
This study was conducted to assess the seasonal variable of cations and anions of a concrete fish tank. Water samples were collected monthly for six month (April-September). Samples were analyzed for the presence and concentration of cations, anions and heavy metals using standard methods of analysis. The highest concentration of cations in the concrete tanks were; magnesium and calcium ions, with a decreasing order of $\mathrm{Mg}^{2+}$ $>\mathrm{Ca}^{2+}>\mathrm{K}^{+}>\mathrm{Na}^{2+}>\mathrm{Fe}^{2+}>\mathrm{NH}_{4}{ }^{+}$, while the highest concentration of anions was sulphate, with a decreasing order of $\mathrm{SO}_{4}^{-}>\mathrm{Cl}^{-}>\mathrm{HCO}_{3}^{-}>\mathrm{PO}_{4}^{3-}>\mathrm{CO}_{3}{ }^{2-}>\mathrm{NO}_{3}^{-}>\mathrm{NO}_{2}^{-}$. Cations were observed to be at higher concentration than the anions. There were generally lower concentrations of heavy metals in the following decreasing order; $M n$ $>\mathrm{Cu}>\mathrm{Pb}>\mathrm{Cr}>\mathrm{Zn}$. Calcium, Mangnesium and Phosphorus were observed to be high during the dry season, while a slight in the concentrations of heavy metals were observed during the raining season. Variations were observed in the concentrations of cations and anions during the periods of six months.
\end{abstract}

Keywords: Cation, anion, concentration, heavy metals, fish, tanks

\section{Introduction}

Water is a medium in which fish live, grows and reproduce, water is therefore every thing to the fish. Any alteration or change in the physico-chemical parameter affects growth and survival of these fish species. Water quality management is very essential in fish production because the growth and reproduction of these fishes depends solely on the quality of the water [1], thus understanding the physico-chemical properties of water is essential for the survival of the fish and other aquatic organism. Heavy metals can be defined as elements that exhibit metallic properties with high density. These may include transition metals, metalloids, lanthanides and actinides. Heavy metals are found naturally, they form components of the lithosphere and can be released into the environment through certain activities amongst which are; volcanism, soil erosion, dissolution of water-soluble salts and weathering of rocks [ $2 \& 3]$. Trace amount of some heavy metals such as zinc, cobalt, strontium and copper are required by living organism, for proper growth and metabolism, but when these heavy metals are in excess they can be detrimental to the living organisms and most often presence of large scale heavy metals in the environment is largely due to human activities [4]. Several authors reported on the varying concentrations of anions and cations on water bodies amongst which are; [5 \& 6]. Several authors also had reported on the concentrations of some heavy metals in large bodies of water [4, 7, 8, $9 \& 10]$. There is little or no work on the concentrations of anions, cations and heavy metals in concrete tanks, thus the need for this study.

\section{Materials and Methods}

\section{Study area}

The study was carried out on three fish concrete tanks belonging to the Department of Forestry and Fisheries Usmanu Danfodio University Sokoto. The University is situated on longitude $4^{\circ} 8$ and $6^{\circ} 54$ and latitudes $12^{\circ} 0$ and $13^{\circ} 38 \mathrm{~N}$.

\section{Sampling Design}

Water samples were collected once in a month, from the three tanks, all collectionhs were made during the morning hours for a period of six months from April to September.

\section{Chemical Analysis}

\section{Carbonate $\left(\mathrm{CO}_{3}{ }^{2-}\right)$ and Bicarbonate $\left(\mathrm{HCO}_{3}\right)$}

Five milliliter $(5 \mathrm{ml})$ of water sample was measured into a conical flask, 5 drops of $1 \%$ phenolhtalein indicator were added. The change in colour to pink indicates the presence of carbonate. The mixture was titrated with $0.1 \mathrm{M}$ of $\mathrm{H}_{2} \mathrm{SO}_{4}$ until the solution became colourless, the titre value was noted and recorded as the value for carbonate in $\mathrm{mg} / \mathrm{L}$. To the same solution, 2 drops of methyl red indicator were added and titrated with $0.1 \mathrm{M}$ of 
$\mathrm{H}_{2} \mathrm{SO}_{4}$ until the colour changed from yellow to rose red. The value of the end point was noted for bicarbonate $\left(\mathrm{HCO}_{3}\right)$ in $\mathrm{mg} / \mathrm{L}[11]$.

\section{Chloride}

To the solution obtained from carbonate and bicarbonate determination, $1 \mathrm{ml}$ of potassium chromate indicator was added and then titrated with $0.05 \mathrm{M} \mathrm{AgNO}_{3}$ (Silver nitrate) solution, $1 \mathrm{ml}$ of $\mathrm{CrO}_{4}$ indicator was added. Clear shade was obtained at the end of the titration [12].

\section{Nitrate Nitrogen (No - N)}

Nitrate - Nitrogen of water was determined using Windaus LF 2400 spectrophotometer. Five millilitre of distilled water was measured into test tube to calibrate the instrument. The water sample was properly shaken before pipetting $5 \mathrm{~m} 1$ into a test tube, one spoonful of nitrate reagent 1 , was added to the sample and shaken. Another spoonful of nitrate reagent II was added to the same water sample in the test tube and then shaken vigorously. The solution in the test was left to stand for 5 minutes. The Windaus LF 2400 spectrophotometer was switched on, and calibrated with distilled water in a test tube (a blank) to zero point. After calibration of the atomic spectrophotometer the wave length was taken and recorded [12].

\section{Nitrate $\left(\mathrm{NO}_{2}\right)$}

Nitrate $\left(\mathrm{NO}_{2}^{-}\right)$of water was determined using Jenway 6100 atomic spectrophotometer [12], $10 \mathrm{ml}$ of water sample was pipetted into $50 \mathrm{~m} 1$ volumetric flask, it was evaporated to dryness on a water bath and allowed to cool. The residue was dissolved in evaporating dish containing $2 \mathrm{~m} 1$ of phenodisulpnonic acid reagent. After 10 minutes, $10 \mathrm{ml}$ of distilled was added and transferred into $100 \mathrm{mI}$ volumetric flask. The content was made alkaline by adding $40 \mathrm{~m} 1$ of $\mathrm{NH}_{4} \mathrm{OH}$ and mixed properly. The absorbance of the yellow solution was read at $460 \mathrm{~mm}$ from the atomic spectrophotometer in $\mathrm{mg} / \mathrm{L}$.

\section{Phosphate Phosphorus}

Phosphate - Phosphorus concentration of water samples were analyzed using Windaus LF 2400 spectrophotometer (AOAC, 1990), 5rnl of distilled water was first measured into a test tube to calibrate the instrument. The water sample was shaken and $5 \mathrm{ml}$ was measured with pipette into a test tube, 12 drops of phosphate reagent 1 was added to the same water sample and shaken. Again 12 drops of phosphate reagent 1 was added to the same water sample in the test tube and shaken vigorously, the solution in the test tube was left to stand for 5 minutes. The spectrophotometer was calibrated. After calibration of the atomic spectrophotometer the wave length was taken and recorded [12].

\section{Sulphate $\left(\mathrm{SO}_{4}{ }^{2-}\right)$}

The concentration of sulphate $\left(\mathrm{SO}_{4}{ }^{2-}\right)$ of the water samples were determined according to AOAC, (1990), 5 $\mathrm{ml}$ of the sample aliquot was measured into $50 \mathrm{ml}$ volumetric flask using pipette, $5 \mathrm{~m} 1$ of $25 \%$ nitric acid $\left(\mathrm{NHO}_{3}\right)$ was added to the sample in the flask further more, $5 \mathrm{ml}$ of $50 \%$ acetic acid and $1 \mathrm{M}$ of $\left(\mathrm{H}_{3} \mathrm{Po}_{4}\right)$ were added to the sample and stirred to mix the content. The solution was diluted to the $50 \mathrm{ml}$ mark of the flask and then mixed again, $1 \mathrm{~g}$ of Bacl2 $-2 \mathrm{H}_{2} \mathrm{O}$ was added to the solution without mixing and allowed to stand for 10 minutes. The flask was inverted twice and again left to stand for another 5 minutes after 10 minutes of inversions of the solution, $1 \mathrm{ml}$ of gum acacia solution was added to make up to $50 \mathrm{~m} 1$ this was inverted several times and allowed to stand for $11 / 2$ hours. Absorbance was taken at a wavelength of $470 \mathrm{~nm}$ from the Jenway 6100 spectrophotometer using distilled water as reference [12].

\section{Ammonium $\left(\mathrm{NH}_{4}^{+}\right)$}

Ammonium ion concentration was determined according to (AOAC, 1990), $5 \mathrm{ml}$ of distilled water was measured into a test tube to calibrate the Windaus LF 2400 spectrophotometer. The water sample was shaken and $5 \mathrm{~m} 1$ was measured with pipette into a test tube, 2 teaspoonful of ammonium reagent I was added to the water sample and shaken. Again 2 spoonful of ammonium reagent II was added to the same water sample in the test tube and shaken vigorously. The solution in the test tube was left to stand for five minutes. The spectrophotometer was switched onto ammonium $\left(\mathrm{NH}_{4}{ }^{+}\right)$, distilled water in a test tube (a blank) was fixed onto the instrument and covered to calibrate the spectrophotometer to zero point. After calibration of the atomic spectrophotometer the wave length was taken and recorded [12]. 


\section{Calcium $\left(\mathrm{Ca}_{2}^{+}\right)$}

To determine the concentration of calcium $\left(\mathrm{Ca}_{2}{ }^{+}\right) 100 \mathrm{ml}$ of water sample was measured into conical flask, 10 drops each of hydroxalamine hydrochloride, potassium ferocyanide and trithalamine were added to the solution, $10 \mathrm{ml}$ of sodium hydroxide buffer was added to stabilize the $\mathrm{pH}$ of the solution and then vigorously shaken. After which $0.3 \mathrm{~g}$ of the murexide (indicator) was added thus changing the colour to pink. The solution was then titrated with $0.02 \mathrm{M}$ EDTA until the colour changed from pink to maroon. The titre value was then recorded in $\mathrm{mg} / \mathrm{L}$ [12].

Iron $\left(\mathrm{Fe}^{2+}\right)$

Iron $\left(\mathrm{Fe}^{2+}\right)$ concentration of the water sample was analyzed using Jenway 6100 atomic spectrophotometer (AOAC, 1990), $10 \mathrm{ml}$ of the water sample was measured into $50 \mathrm{ml}$ volumetric flask, $5 \mathrm{~m} 1$ of thiogilycolic acid solution was added together with $2 \mathrm{~m} 1$ of $20 \%$ ammonium titrate solution and $5 \mathrm{ml}$ of diluted ammonium hydroxide solution. The solution was vigorously shaken; distilled water was added to make up the solution. After calibration of the atomic spectrophotometer the wave length was taken and recorded [12].

\section{Potassium $\left(\mathrm{K}^{+}\right)$and Sodium $\left(\mathrm{Na}^{+}\right)$}

The determination of potassium $\left(\mathrm{K}^{+}\right)$and sodium $\mathrm{Na}^{+}$) ions of water samples were determined using Corning 400 atomic flame photometry. The photometer was switched on, the gas cylinder was also opened to aid the passage of gas to the flame chamber of the photometer before ignited. The photometer was then calibrated with sodium and potassium standard $(\mathrm{NaCI}$ and $\mathrm{KCl})$. The colour of the ignition flame for potassium was blue flame and for sodium golden. The concentrations of potassium $(\mathrm{K})$ and sodium $(\mathrm{Na})$ were calculated from the standard.

\section{Analysis of Heavy Metals Copper $(\mathbf{C u})$}

Copper $(\mathrm{Cu})$ concentration was determined using Jenway 6100 spectrophotometer, $5 \mathrm{~m} 1$ water sample was pipetted into $100 \mathrm{ml}$ volumetric flask. Blank was equally treated the same way. About $10 \mathrm{ml}$ of $2.5 \mathrm{M}$ of $\mathrm{H}_{2} \mathrm{SO}_{4}$ with $30 \mathrm{rn} 1$ of distilled water were added and properly mixed with $5 \mathrm{~m} 1$ of zinc dibenyldithio carbonate. The flask was corked and shaken for 10 minutes. It was allowed to stand for 10 minutes until the phases separated, the water phase was sucked off and filter over water repellent paper into a test tubes. Copper concentration was calculated as follows;

$$
\begin{array}{cl}
\mathrm{Cu}(\mathrm{mg} / \mathrm{l})=\mathrm{a}-\mathrm{b} \times \underline{\mathrm{v}} & \begin{array}{l}
\text { Where: } \mathrm{a}=\text { Concentration of } \mathrm{Cu} \text { in the sample } \\
\mathrm{d}
\end{array} \\
\mathrm{b}=\text { Concentration of cu in the blank } \\
\mathrm{d}=\text { Volume of solution (total volume made) }
\end{array}
$$

\section{Chromium (Cr)}

Chromium $(\mathrm{Cr})$ concentration was determined using Jenway 6100 atomic spectrophotometer, $50 \mathrm{mI}$ of the water sample was pipetted into $250 \mathrm{ml}$ flask, $5 \mathrm{ml}$ of $3 \mathrm{MH}_{2} \mathrm{SO}_{4}$ and $5 \mathrm{ml}$ of $\mathrm{N}$ phenyl antracic acid were added to the sample solution. Distilled water was added to make the volume of the solution up to the $250 \mathrm{ml}$ mark. The concentration of Chromium $(\mathrm{Cr})$ was taken at the wavelength of $283.3 \mathrm{~nm}$ in $\mathrm{mg} / \mathrm{L}$.

\section{Manganese (Mn)}

Manganese (Mn) concentration of water was determined according to AOAC, (1990) by using Jenway 6100 atomic spectrophotometer, $5 \mathrm{~m} 1$ of water sample was pipetted into a test tube together with the blanks, $1 \mathrm{ml}$ of $0.08 \mathrm{M} \mathrm{H}_{2} \mathrm{SO}_{4}$ was added to the sample. The racks together with the test tube were placed in the fume cupboard of the spectrophotometer, $0.05 \mathrm{~m} 1$ of menthol solution was added to the solution and mixed, $0.5 \mathrm{~m} 1$ of cyanide solution was added and then mixed for 15 minutes. Drops of formal dioxin solution was added to the solution and mixed immediately. After 30 minutes the absorbance was taken at wave length of $500 \mathrm{~nm}$.

\section{Zinc (Zn)}

The concentration of $\mathrm{Zn}$ in the water sample was determined using Jenway 6100 spectrophotometer, $5 \mathrm{ml}$ of the water sample was pipetted into $50 \mathrm{~m} 1$ volumetric flask, $15 \mathrm{ml}$ of $0.12 \mathrm{M}$ HCL was added. Blank was equally treated in the same way. To the sample and blank, $1 \mathrm{~m}$ of citric acid solution was added, 3 drops of cresol red indicator in ammonia solution were also added until the colour changed from red to purple. The solution was thoroughly mixed and $10 \mathrm{mI}$ of dithriiozone solution was added. Little distilled water was also added and shaken for 10 minutes. After 20 minutes, the absorbance was read at a wavelength of $620 \mathrm{~nm}$. 


\section{Cationic Concentrations}

\section{Results}

Calcium ion level of $20.10 \pm 0.32 \mathrm{mg} / \mathrm{L}$ was found to be at its peak in May during late dry season and gradually decreased from June of early rainy season to its minimum level of $8.5 \pm 0: 20 \mathrm{mg} / \mathrm{L}$ in August during the rainy season. The concentration of magnesium ion of water in the tank was highest with a value of $5.33 \pm 0.35 \mathrm{mg} / \mathrm{L}$ in April during the late dry season and decreased significantly $(\mathrm{P}<0.05)$ to a value of $31.2 \pm 0.40 \mathrm{mg} / \mathrm{L}$ in May of the same season. However, the concentration increased gradually from June to July during the early rainy season and further decreased to a minimum of $16.3 \pm 0.35 \mathrm{mg} / \mathrm{L}$ in August of the flood season with overall mean value of 31.7 $\pm 13.78 \mathrm{mg} / \mathrm{L}$. Sodium ion gradually increases from lower level of $0.63 \pm 0.15 \mathrm{mg} / \mathrm{I}$ in April during the late dry season to higher level of $0.81 \pm 0.01 \mathrm{mg} / \mathrm{L}$ in July of early rainy season. The level again decreased to the lowest value of $0.6 \pm 0.01 \mathrm{mg} / \mathrm{L}$ in August and eventually rose to a peak of $1.2 \pm 0.01 \mathrm{mg} / \mathrm{L}$ in September of the rainy season. Potassium ion concentration increased from a lower level of $1.01 \pm 0.01 \mathrm{mg} / \mathrm{L}$ in April during the late dry season to higher level of $2.00 \pm 0.10 \mathrm{mg} / \mathrm{L}$ in July during the early rainy season, the level again deceased to the lowest level of $1.60 \pm 010 \mathrm{mg} / \mathrm{L}$ in August and eventually rose to the peak $(1.60 \pm 0.10 \mathrm{mg} / \mathrm{L})$ in September. Iron concentration varied with narrow amplitude across the months, the lowest level of $0.14 \pm 0.02 \mathrm{mg} / \mathrm{L}$ was recorded in June of the early rainy season, while the highest concentration of $0.50 \pm 0.10 \mathrm{mg} / \mathrm{L}$ was observed in August of the rainy season. With average of $0.29 \pm 0.11 \mathrm{mg} / \mathrm{L}$ ammonium ion level was at maximum level of $0.16 \pm 0.04 \mathrm{mg} / \mathrm{L}$ in May of late dry season. It further decreased minimally from June of early rainy season to September of the flood season with average concentration of $0.14 \pm 0.01 \mathrm{mg} / \mathrm{L}$, as shown in Table 1 .

Table 1: Mean Monthly Cationic Parameters, Of Concrete Fish Tank

\begin{tabular}{|c|c|c|c|c|c|c|c|}
\hline \multirow[t]{2}{*}{ PARAMETERS } & \multicolumn{7}{|l|}{ MONTHS } \\
\hline & APRIL & MAY & JUNE & JULY & AUGUST & SEPTEMBER & $\mathrm{X} \pm \mathrm{SD}$ \\
\hline Calcium & $11.30 \pm 0.36^{\mathrm{c}}$ & $20.10 \pm 0.32^{\mathrm{a}}$ & $16.20 \pm 0.20^{\mathrm{b}}$ & $12.20 \pm 0.32^{\mathrm{c}}$ & $8.50 \pm 0.20^{\mathrm{d}}$ & $9.10 \pm 0.11^{\mathrm{d}}$ & $12.90 \pm 4.46^{\mathrm{c}}$ \\
\hline Magnesium & $53.40 \pm 0.35^{\mathrm{a}}$ & $31.20 \pm 0.40^{\mathrm{c}}$ & $35.10 \pm 0.10^{\mathrm{bc}}$ & $37.10 \pm 0.30^{\mathrm{b}}$ & $16.30 \pm 0.35^{\mathrm{d}}$ & $17.50 \pm 0.30^{\mathrm{d}}$ & $31.70 \pm 13.78^{\mathrm{c}}$ \\
\hline Sodium & $0.63 \pm 0.15^{\mathrm{b}}$ & $0.72 \pm 0.02^{\mathrm{b}}$ & $0.78 \pm 0.01^{\mathrm{b}}$ & $0.81 \pm 0.01^{b}$ & $0.60 \pm 0.01^{\mathrm{b}}$ & $1.20 \pm 0.01^{\mathrm{a}}$ & $0.79 \pm 0.21^{\mathrm{b}}$ \\
\hline Potassium & $1.01 \pm 0.01^{b}$ & $1.20 \pm 0.20^{\mathrm{b}}$ & $1.60 \pm 0.02^{b}$ & $1.90 \pm 0.01^{\mathrm{ab}}$ & $1.60 \pm 0.10^{b}$ & $2.60 \pm 0.10^{\mathrm{a}}$ & $1.65 \pm 0.56^{b}$ \\
\hline Iron & $0.25 \pm 0.05^{\mathrm{a}}$ & $0.30 \pm 0.10^{\mathrm{a}}$ & $0.14 \pm 0.02^{\mathrm{a}}$ & $0.25 \pm 0.05^{\mathrm{a}}$ & $0.50 \pm 0.10^{\mathrm{a}}$ & $0.30 \pm 0.11^{\mathrm{a}}$ & $0.29 \pm 0.11^{\mathrm{a}}$ \\
\hline Ammonium & $0.16 \pm 0.04^{\mathrm{a}}$ & $0.16 \pm 0.04^{\mathrm{a}}$ & $0.15 \pm 0.03^{\mathrm{a}}$ & $0.14 \pm 0.02^{\mathrm{a}}$ & $0.14 \pm 0.01^{\mathrm{a}}$ & $0.11 \pm 0.01^{\mathrm{a}}$ & $0.14 \pm 0.01^{\mathrm{a}}$ \\
\hline
\end{tabular}

\section{Anionic Composition}

As shown in Table 2, there was gradual fluctuation in the concentration of Bicarbonate from April of late dry season to September. However, the maximum value of $18.3 \pm 0.20 \mathrm{mg} / \mathrm{L}$ was recorded in September during the rainy season with a mean concentration of $8.93 \pm 6.62 \mathrm{mg} / \mathrm{L}$. carbonate ion level was at its highest concentration of $2.17 \pm 0.01 \mathrm{mg} / \mathrm{L}$ in June of early rainy season and decreased gradually from July of the same season to August. However, there was no trace of carbonate ion level in the tank water in the month of April of late dry season.

Sulphate ion concentration increased from the lowest value of $3.8 \pm 0.25 \mathrm{mg} / \mathrm{L}$ in May of late dry season to a significant $(\mathrm{P}<0.05)$ peak value of $34.1 \pm 15.9 \mathrm{mg} / \mathrm{L}$ in the month of August during the peak of the rainy season. However the overall mean concentration of Sulphate ion in the water body was $12.5 \pm 11.6 \mathrm{mg} / \mathrm{L}$. Nitrate ion concentration was at its lowest value of $0.01 \pm 0.00 \mathrm{mg} / \mathrm{L}$ in April of late dry season and increased gradually from May of the same season to the highest level of $1.2 \pm 0.30 \mathrm{mg} / \mathrm{L}$ in August, it again decreased to a lower level in September of the same season with a mean concentration of $061 \pm 0.01 \mathrm{mg} / \mathrm{L}$. Nitrite ion level was highest with a value of $0.70 \pm 0.01$ $\mathrm{mg} / \mathrm{L}$ in the month of June and lowest during the month of May with a mean value of $0.02 \pm 0.00 \mathrm{mg} / \mathrm{L}$.

Chloride ion concentration was observed to have increased gradually with a mean value of $5.4 \pm 0.30 \mathrm{mg} / \mathrm{L}$ in May of late dry season to a maximum value of $16.1 \pm 0.15 \mathrm{mg} / \mathrm{L}$ in September during the flood season. Phosphorus ion concentration was at its maximum level of $9.37 \pm 0.06 \mathrm{mg} / \mathrm{L}$ in April of late dry season and decreased gradually to a mean value of $011 \pm 0.01 \mathrm{mg} / \mathrm{L}$ as the rainy season advances (Table 2).

Table 2: Mean Monthly Anionic Parameters of Concrete Fish Tank

\begin{tabular}{|l|l|l|l|l|l|l|l|}
\hline \multirow{2}{*}{ Parameters } & Months & \multicolumn{5}{l|}{} \\
\cline { 2 - 8 } & April & May & June & July & August & September & X \pm SD \\
\hline Biocarbonate & $4.00 \pm 0.51^{\mathrm{c}}$ & $4.70 \pm 0.15^{\mathrm{c}}$ & $3.60 \pm 0.11^{\mathrm{c}}$ & $6.60 \pm 0.15^{\mathrm{b}}$ & $16.40 \pm 0.15^{\mathrm{a}}$ & $18.30 \pm 0.20^{\mathrm{a}}$ & $8.93 \pm 6.62^{\mathrm{b}}$ \\
& & & & & & & \\
& & & & & & & \\
\hline Carbonate & $0.00 \pm 0.00^{\mathrm{c}}$ & $1.10 \pm 0.10^{\mathrm{b}}$ & $2.17 \pm 0.01^{\mathrm{a}}$ & $1.20 \pm 0.20^{\mathrm{b}}$ & $0.73 \pm 0.15^{\mathrm{b}}$ & $1.20 \pm 0.25^{\mathrm{ab}}$ & $1.06 \pm 0.70^{\mathrm{b}}$ \\
\hline Sulphate & $16.80 \pm 0.26^{\mathrm{b}}$ & $3.80 \pm 0.25^{\mathrm{e}}$ & $6.06 \pm 0.01^{\mathrm{d}}$ & $10.10 \pm 0.20$ & $34.10 \pm 15.90^{\mathrm{a}}$ & $4.20 \pm 0.30^{\mathrm{e}}$ & $12.50 \pm 11.60^{\mathrm{c}}$ \\
\hline Nitrate & $0.50 \pm 0.00^{\mathrm{a}}$ & $0.02 \pm 0.01^{\mathrm{c}}$ & $0.70 \pm 0.01^{\mathrm{a}}$ & $0.11 \pm 0.00^{\mathrm{b}}$ & $0.21 \pm-0.01^{\mathrm{b}}$ & $0.15 \pm 0.01^{\mathrm{b}}$ & $0.17 \pm 0.07^{\mathrm{b}}$ \\
\hline Chloride & $13.00 \pm 0.20^{\mathrm{bc}}$ & $5.40 \pm 0.30^{\mathrm{d}}$ & $5.00 \pm 0.15^{\mathrm{d}}$ & $4.60 \pm 0.05^{\mathrm{d}}$ & $15.00 \pm 0.15^{\mathrm{a}}$ & $16.10 \pm 0.15^{\mathrm{a}}$ & $9.8 \pm 5.14^{\mathrm{b}}$ \\
\hline
\end{tabular}


Seanonal Variation of Cations and Anions in a Concrete Fish Tank

\begin{tabular}{|l|l|l|l|l|l|l|l|}
\hline Phosphorus & $9.37 \pm 0.60^{\mathrm{a}}$ & $3.00 \pm 0.10^{\mathrm{b}}$ & $1.90 \pm 0.10^{\mathrm{c}}$ & $0.12 \pm 0.01^{\mathrm{d}}$ & $0.24 \pm 0.05^{\mathrm{d}}$ & $0.11 \pm 0.01$ & $2.45 \pm 3.58^{\mathrm{b}}$ \\
\hline
\end{tabular}

\subsection{Heavy Metals Concentrations}

Zinc concentration varied from the lowest value of $0.01 \pm 0.00 \mathrm{mg} / \mathrm{L}$ in June and July of early rainy season to a maximum value of $0.06 \pm 0.01 \mathrm{mg} / \mathrm{L}$ in August of the flood season. The average concentration of Zinc in the concrete tank water was $0.02 \pm 0.01 \mathrm{mg} / \mathrm{L}$. Copper level increased gradually from the lowest level of $0.01 \pm 0.01$ $\mathrm{mg} / \mathrm{L}$ in May of late dry season to a maximum level of $0.31 \pm 0.01 \mathrm{mg} / \mathrm{L}$ in September during the rainy season. Manganese concentration increased significantly $(\mathrm{P}>0.05)$ from April $(0.20 \pm 0.00 \mathrm{mg} / \mathrm{L})$ to May $(0.31 \pm 0.01 \mathrm{mg} / \mathrm{L})$ of late dry season and decreased from the value of $0.21 \pm 0.01 \mathrm{mg} / \mathrm{L}$ in June to the lowest value of $0.11 \pm 0.01 \mathrm{mg} / \mathrm{L}$ in July of early rainy season. However, manganese concentration rose to the maximum level of $0.41 \pm 0.01 \mathrm{mg} / \mathrm{I}$ in August of the rainy season. $0.10 \mathrm{mg} / \mathrm{i}$. there was no significant variation in the concentration of lead across the months and seasons. However, lead concentration increased slightly from lower levels of $0.10 \pm 0.00 \mathrm{mg} / \mathrm{L}$ from late dry season (April and May) and remained at high levels of $0.11 \pm 0.01 \mathrm{mg} / \mathrm{L}$ throughout the rainy season. Chromium concentration was at a peak of $0.05 \pm 0.01 \mathrm{mg} / \mathrm{L}$ in April of late dry season. The concentration gradually decreased and remained at lower levels from May $(0.02 \pm 0.01 \mathrm{mg} / \mathrm{L})$ to September $(0.02 \pm 0.01 \mathrm{mg} / \mathrm{L})$ during the rainy season (Table 3).

Table 3: Mean Monthly Heavy Metals Parameters Of Fish Tank

\begin{tabular}{|l|l|l|l|l|l|l|l|}
\hline \multirow{2}{*}{ PARAMETERS } & MONTHS & \multicolumn{5}{l|}{} \\
\cline { 2 - 8 } & APRIL & MAY & JUNE & JULY & AUGUST & SEPTEMBER & X \pm SD \\
\hline Zinc & $0.02 \pm 0.00^{\mathrm{a}}$ & $0.01 \pm 0.01^{\mathrm{a}}$ & $0.01 \pm 0.00^{\mathrm{a}}$ & $0.01 \pm 0.00^{\mathrm{a}}$ & $0.06 \pm 0.04^{\mathrm{a}}$ & $0.01 \pm 0.00^{\mathrm{a}}$ & $0.02 \pm 0.01^{\mathrm{a}}$ \\
\hline Copper & $0.21 \pm 0.01^{\mathrm{b}}$ & $0.01 \pm 0.01^{\mathrm{c}}$ & $0.15 \pm 0.01^{\mathrm{b}}$ & $0.20 \pm 0.00^{\mathrm{b}}$ & $0.30 \pm 0.01^{\mathrm{b}}$ & $0.31 \pm 0.01^{\mathrm{b}}$ & $1.19 \pm 0.11^{\mathrm{a}}$ \\
\hline Manganese & $0.20 \pm 0.00^{\mathrm{a}}$ & $0.31 \pm 0.01^{\mathrm{a}}$ & $0.21 \pm 0.01^{\mathrm{a}}$ & $0.11 \pm 0.01^{\mathrm{a}}$ & $0.41 \pm 0.01^{\mathrm{a}}$ & $0.21 \pm 0.01^{\mathrm{a}}$ & $0.24 \pm 0.10^{\mathrm{app}}$ \\
\hline Lead & $0.10 \pm 0.00^{\mathrm{a}}$ & $0.10 \pm 0.01^{\mathrm{a}}$ & $0.11 \pm 0.01^{\mathrm{a}}$ & $0.11 \pm 0.01^{\mathrm{a}}$ & $0.11 \pm 0.01^{\mathrm{a}}$ & $0.11 \pm 0.01^{\mathrm{a}}$ & $0.10 \pm 0.009^{\mathrm{a}}$ \\
\hline Chromium & $0.05 \pm 0.01^{\mathrm{b}}$ & $0.02 \pm 0.01^{\mathrm{b}}$ & $0.20 \pm 0.01^{\mathrm{a}}$ & $0.02 \pm 0.00^{\mathrm{b}}$ & $0.10 \pm 0.01^{\mathrm{a}}$ & $0.02 \pm 0.01^{\mathrm{b}}$ & $0.03 \pm 0.03^{\mathrm{b}}$ \\
\hline
\end{tabular}

\section{Discussion}

The chemical parameters (cations, inions and heavy metals) of the concrete fish tanks exhibited significant $(\mathrm{P}<0.05)$ seasonal fluctuation during the period of the study. However, variations observed in the parameters were within the requirement for fish production in natural fresh water bodies. Magnesium and calcium were found to be the most dominant cations in the concrete fish tanks. These concentrations were found to be below the optimum level of $100 \mathrm{mg} / \mathrm{L}$ required for fish production [13]. Sodium and potassium were found to occur in trace levels in the tanks. The lower concentrations of sodium and potassium ions observed during the dry season when compared with the rainy season could be due to rapid utilization of the ions by phytoplankton for photosynthesis during intense solar radiation. Bicarbonate ion concentration was higher in the rainy season than in the dry season most probably due to removal of carbondioxide from the water for photosynthesis by phytoplankton as early reported by Golterman [14] and it could be due to the rapid evaporation of tank water during the dry season. The solubility of this ion however serves as the main buffer system for regulating the $\mathrm{pH}$ of the pond water.

Sulphate, chloride and bicarbonate were the dominant anions in the concrete fish tank. However, sulphate and chloride ions exhibited similar trends across the months and seasons, the higher concentrations of these ions in August during the rainy season could be attributed to inflows of allocthonous materials into the pond from agricultural soil and the and adjoining water shed during torrential rainfall. Nitrate ion concentration was higher in the rainy season than in the dry season this might be due to inflows of fertilizer from farmlands, organic materials and effluents from domestic waste in the catchments areas of the source of water for the fish tank. However, the higher concentration of phosphorus observed during the dry season than in the rainy season may be attributed to decrease in water level due to high rate of evaporation during the dry season, which resulted in higher concentration of dissolved minerals substances.

The heavy metals investigated were found to be at lower concentrations across the seasons this might be due to precipitation of the metals as carbonate in the presence of calcium and magnesium ions in the concrete fish tank as reported by Lyorid, [15]. However, the concentration of all the heavy metals were observed to be at higher levels in August of the rainy season most probably due to effluent drainage from the generator plant, chemical laboratories, in the catchments areas of the concrete fish tanks.

\section{Conclusion and Recommendations}

The study shows the influence of seasons on water quality parameters (Cations, anions and heavy metals) of concrete fish tank, the variations in these chemical characteristics were within the water quality standard 
requirement for, fish production in fresh water bodies. The lower concentrations of the heavy metals observed in most of the months during this study could suggest little pollution of the concrete fish tanks. However the higher level of heavy metals observed in the month of August during the rainy season brought to the fore front the need for monitoring of the source of water as management strategy for ensuring good quality of the tank water for optimum fish production.

In conclusion, the results of this study serve as a baseline data that could be useful in ensuring good quality water for optimum fish productivity.

\section{References}

[1]. Fergusson, J. E. (1990). The Heavy elements: Chemistry, environment impact and health effects. Pergamon Press, Oxford, England.

[2]. Mahavi, A. H., Nouri, J., Babaei, A. A. and Nabizadeh, R. (2005). Agricultural activities impact on ground water nitrate pollution. Int. J. Environ. Sci. Tech., 2(1): 41-47.

[3]. Liao, S. W., Gau, H. S., Lai, W. L., Chen, J. J., Lee, C. G. (2007). Identificaion of pollution of tapeng Lagoon from neighbouring rivers using multivariate statistical method. J. Environ. Manag., 88 (2): 286-292.

[4]. Obaroh, I. O., Elinge, M. and Nwankwo, C. (2012) Assessment of some Heavy Metals and Physico-chemical Parameters of Jega River, North West Nigeria. International Journal of Natural and Applied Sciences. 8(1): 78-81.

[5]. Olayinka, K. O. (2004). Studied on industrial pollution in Nigeria; the effect of textile effluents on the quality of ground water in some parts of Lagos. Nigeria Journal of Health and Biomedical Sciences. 3, 27-30.

[6]. Essoka, P. A. and Umaru, J. M. (2006). Industrial effluent and water pollution in Kakuri area, Kaduna South, Nigeria. Journal of Industrial Pollution and Control. 22(1):

[7]. Eniola, E. B., Chukwu, L. O. and Olaide, B. S. (2010). Hydro-Chemistry, macro-invertebrate fauna and fish production of Acdja fishing sites in a tropical lagoonal ecosystem. Journal of American Sciecne. 6(1):1-14

[8]. Asonye, C. C., Okolie, N. P., Okenwa, E. E. and Iwuanyanwu, U. G. (2007). Some physico-chemical characteristics and heavy metal profiles of Nigeria rivers, streams and waterways. African Journal of Biotechnology, 6(5): 617 - 624.

[9]. APHA, (1990). Standard Methods of Water and Wastewater. $18^{\text {th }}$ ed. American Public Health Association, American Water works Association. Water Environment Federation Publication. Washington D. C. pp 460-472.

[10]. AOAC (1990) Official Methods of Analysis of the Association of Official Analytical Chemist (AOAC) in heiricuk (ed). Association of official chemist mc: New York Pop. 50-58

[11]. Delince, 0(1992). The Ecology of the fishpond Ecosystem with special reference to Africa Kiuwer Academic Pub. London Britain, 205 p.

[12]. Golterman, H. L. (1975). Primary Pioduction hj Relation to Photosynthesis Under Natural Conditions. In: Golterman H.L (ed)SeminarLimnology. Oxford Elser,ier Pub. Amsterdam. Pp.66-96.

[13]. Ipinjolu, J. K. and Agungu, L. A. (1998). The chemical and biological properties of water sources in the Zamfara reserve. Giessener Beitrage Zur Entwickllungsforschung Reihe 1. 25: 31-40.

[14]. Jegessar, R. C. and Sooknundun, L. (2011). Determination of nitrate anion in waste water from nine selected areas of coastal Guayana via a spectrophotometric method. IJRRAS, 7 (2): $203-212$.

[15]. Lyorid R. (1992). Pollution and Fresh water fish. 1st edition. Balackwell scientific Publicatioh In: London, Britain: 176 p. 